\title{
Does chemical index of alteration (CIA) reflect silicate weathering and monsoonal climate in the Changjiang River basin?
}

\author{
SHAO JingQing \& YANG ShouYe* \\ State Key Laboratory of Marine Geology, Key Laboratory of Yangtze River Water Environment, Ministry of Education, Tongji University, \\ Shanghai 200092, China
}

Received August 3, 2011; accepted December 9, 2011; published online January 31, 2012

\begin{abstract}
Chemical weathering of continental silicates significantly influences global climate change, earth surface processes, material cycling and oceanic chemical composition. How to quantitatively reconstruct chemical weathering history has become an important issue in global change research. Chemical index of alteration (CIA) has been widely used as a quantitative indicator for estimating the degree of silicate weathering. However, its method of calculation and the limitations of its application are not well understood. In this study, we calculated CIA values from suspended particulate matter collected from the mainstream and major tributaries of the Changjiang River. The values yielded considerable variations at different temporal and spatial scales. The average CIA values increased from the upper to middle-lower reaches, and were lower in the suspended samples taken during the flood than in the dry season. The spatial variation in the CIA is predominantly controlled by basinal monsoon climate. In contrast, the temporal variation in the Changjiang River basin is controlled mainly by the changing provenance of suspended samples in relation to the shift of the precipitation zone. The CIA probably indicates the integrated weathering history in the river basin, and thus, cannot be used as a reliable proxy of instantaneous chemical weathering. Furthermore, the calculation method and hydrodynamic sorting also influence the CIA values. Therefore, caution should be taken when using the CIA as a proxy for studying chemical weathering from different regions.
\end{abstract}

Changjiang river, chemical weathering, CIA, suspended particulate matter, climate

Citation: Shao J Q, Yang S Y. Does chemical index of alteration (CIA) reflect silicate weathering and monsoonal climate in the Changiang River basin? Chin Sci Bull, 2012, 57: 1178-1187, doi: 10.1007/s11434-011-4954-5

Global tectonic movement during the Cenozoic, in particular the uplift of the Himalayan-Tibetan Plateau and its environmental effect, have been widely highlighted in earth system science and global change research since Raymo et al. [1] proposed the "tectonic uplift-weathering" hypothesis. The Tibetan uplift fostered the Asian monsoon climate and major river systems. Chemical weathering in these river basins plays a key role in earth surface processes and geochemical cycles in supergene environments, including the global carbon cycle and the chemical composition of the oceans [2-7]. The quantitative evaluation of the degree of chemical weathering in continents and paleoclimate reconstruction is becoming of increased importance. Many stud-

*Corresponding author (email: syyang@ tongji.edu.cn) ies have proposed different chemical weathering indices based on sediment geochemical analyses [8-16]. Nesbitt and Young [9] first proposed the chemical index of alteration (CIA) in their study of early Proterozoic lutite in Canada to calculate the degree of feldspar mineral weathering to clay. Over the last thirty years, CIA has been extensively applied to indicate the intensity of silicate weathering in basins in many continents, e.g. the Amazon River [17,18], the Changjiang (Yangtze) River and Huanghe (Yellow) River [19,20], South Asian (Indus, Red, Mekong and Ganges) rivers [21-24], Luzon in southeast Asia [25], Taiwan rivers [26], the West Sichuan Plateau [27] and the North China Plain [28]. McLennan [29] calculated the CIA value of suspended particulate matter (SPM) from 16 major rivers in the world and found that the degree of weathering was 
statistically correlated with the physical denudation rates in these catchments. Recently, Li and Yang [20] systematically investigated the CIA values in SPM samples from 44 major rivers from seven continents, and discussed the correlations between CIA and drainage area, annual average temperature, rainfall, runoff, and soil layer thickness. On a global scale, CIA is sensitive to average annual temperature, soil layer thickness and latitude, whereas chemical weathering in the river basins of China is strongly affected by monsoonal climate [20]. Furthermore, weathering intensity is controlled by temperature, rainfall and runoff as these Chinese catchments are mostly latitudinal. Although these previous studies have significantly increased our understanding of the CIA application, the calculation method of CIA and its significance and limitations to trace chemical weathering are less understood. For example, the temporal and spatial variations of CIA values in the sediments of a single river have never been studied, and moreover, whether CIA can indicate seasonal climate change in basins remains to be clarified.

The Changjiang River is the longest river that originates from the Tibetan Plateau, and its historic development records the late Cenozoic tectonic uplift, Asian monsoon evolution and continental weathering regime. Thus, it has been of scientific interest over the past hundred years. The Changjiang River sediments are regarded as a mixture of weathered material of various source rocks in the catchment and thus, can reflect the average composition of weathered continental crust and record the drainage weathering history $[19,30]$. In this study, the SPM samples from the mainstream and major tributaries of the Changjiang River were measured and CIA values were calculated. The major aims of this study were to examine the spatial and temporal variations of CIA values and to discuss to the relationship between sediment source, changing monsoon rain in the basin and CIA application for tracing silicate weathering. In addition, we used different methods to calculate and compare CIA values and discuss some of the existing problems in using CIA.

\section{Sample sources and methodology}

\subsection{Sample collection}

SPM samples from the mainstream and major tributaries of the Changjiang River were collected during the flood seasons of 2001, 2004, 2008 and 2009, with localities ranging from the upper Jinsha River downstream to the estuary (Table 1). In addition, seasonal SPM samples were collected weekly from the lower mainstream near Nantong City from April 2008 to 2009. All of the SPM samples were taken from near the center of the main river channel. At each sampling site, $\sim 25 \mathrm{~L}$ of water was collected from $1 \mathrm{~m}$ below the river surface and filtered in situ through a $0.45 \mu \mathrm{m}$ membrane of cellulose acetate to collect particulate matter.
These samples were dried in oven at $40^{\circ} \mathrm{C}$, and subsequently ground for chemical analysis.

\subsection{Analytical methods and CIA calculation}

Fifty-one seasonal samples from near Nantong were leached with $1 \mathrm{~mol} / \mathrm{L}$ high-purity hydrochloric acid $(\mathrm{HCl})$ in order to examine the influence from the different calculation methods on the CIA value. The acid leachable and insoluble residue samples were separately measured for elemental concentrations. The powdered samples were ignited in a muffle furnace at $600^{\circ} \mathrm{C}$ for $2 \mathrm{~h}$ to remove organic matter before chemical determination. About $0.03 \mathrm{~g}$ samples were digested with $\mathrm{HNO}_{3}$ and HF in a tightly closed Teflon vessel on a hot plate. Major elements were determined by ICP-AES (IRIS Advantage ICP-AES) at the State Key Laboratory of Marine Geology at Tongji University, China. The analytical precision and accuracy using the international geostandard (GSD) serials were $>95 \%$.

CIA can be defined as $\mathrm{Al}_{2} \mathrm{O}_{3} /\left(\mathrm{Al}_{2} \mathrm{O}_{3}+\mathrm{CaO} *+\mathrm{Na}_{2} \mathrm{O}+\mathrm{K}_{2} \mathrm{O}\right)$ $\times 100$ (eq. (1)). Each oxide denotes the molar content, where $\mathrm{CaO}^{*}$ is the amount of $\mathrm{CaO}$ incorporated in silicate fraction of the samples measured and excludes $\mathrm{CaO}$ combined in carbonate and phosphate minerals [9]. Therefore, the CIA actually reflects the degree of aluminum silicate minerals, especially feldspar weathered to clay minerals [12,31]. The higher the CIA value indicates the stronger chemical weathering and the more leaching of Na-, K- and Ca-bound minerals from parent rocks $[32,33]$. As it is difficult to accurately separate silicate minerals from the bulk samples, sediments were leached by $1 \mathrm{~mol} / \mathrm{L} \mathrm{HCl}$ to leave $\mathrm{CaO}^{*}$ that was incorporated in silicate minerals. The $\mathrm{CaO}$ content in the residue fraction was thus used for CIA calculation. Previous studies revealed that $1 \mathrm{~mol} / \mathrm{L} \mathrm{HCl}$ can effectively dissolve carbonate, phosphate, some authigenic Fe-Mn oxide minerals and a small amount of clay mineral such as chlorite [34,35]. In addition, many studies on CIA do not use an acid leaching method to remove non-silicate minerals, but adopt the correction method proposed by McLennan [29], which suggests that $\mathrm{CaO}^{*}$ can be estimated by assuming reasonable $\mathrm{Ca} / \mathrm{Na}$ ratios in silicate material. If the $\mathrm{CaO}$ molar content is less than that of $\mathrm{Na}_{2} \mathrm{O}$, measured $\mathrm{CaO}$ content can be used for $\mathrm{CaO}^{*}$; while $\mathrm{CaO}$ molar content is greater than that of $\mathrm{Na}_{2} \mathrm{O}, \mathrm{CaO}^{*}$ it is assumed to be equivalent to $\mathrm{Na}_{2} \mathrm{O}$. In this paper, McLennan's method [29] was applied to calculate CIA values and compared with our acid-leaching method.

\section{Spatial and temporal variations in CIA values in the SPM samples}

\subsection{Spatial variation of CIA values}

The Changjiang River has a basin area approximately $1.8 \times$ $10^{6} \mathrm{~km}^{2}$, and consists of a complex tributary system. Geo- 
graphically, the upper reaches refer to the headwater to Yichang in Hubei Province, the middle reaches from Yichang to Hukou in Jiangxi Province, and the lower reaches from Hukou to the estuary. The CIA values of the SPM samples from the mainstream and major tributaries of the Changjiang River are shown in Table 1.

The CIA values of the SPM samples from the upstream Changjiang River to the lower reaches vary between 65.8 and 77.6, with an average of 72.1. In the upper reaches, the Minjiang River sample in Leshan has the lowest CIA value of 65.8, while the mainstream near Luzhou and Yibin yields the highest CIA values of 72.7. In the mid-lower reaches, the Hanjiang River SPM has a low CIA value (69.1) while the mainstream near Nanjing yields a higher value (77.6). Although the CIA value displays irregular changes from upstream to downstream, the average CIA values are 70.3 with range of 65.8 to 72.7 in the upstream and 74.1 with range of 69.1 to 77.6 in the mid-lower reaches, reflecting regional variation (Figure 1). The average CIA value from the Changjiang River SPM samples are 72.1, equal to the average value of world rivers estimated by Li and Yang [20], slightly higher than the average by McLennan [29], and

Table 1 Contents of major oxides and CIA values in the SPM samples from the Changjiang River

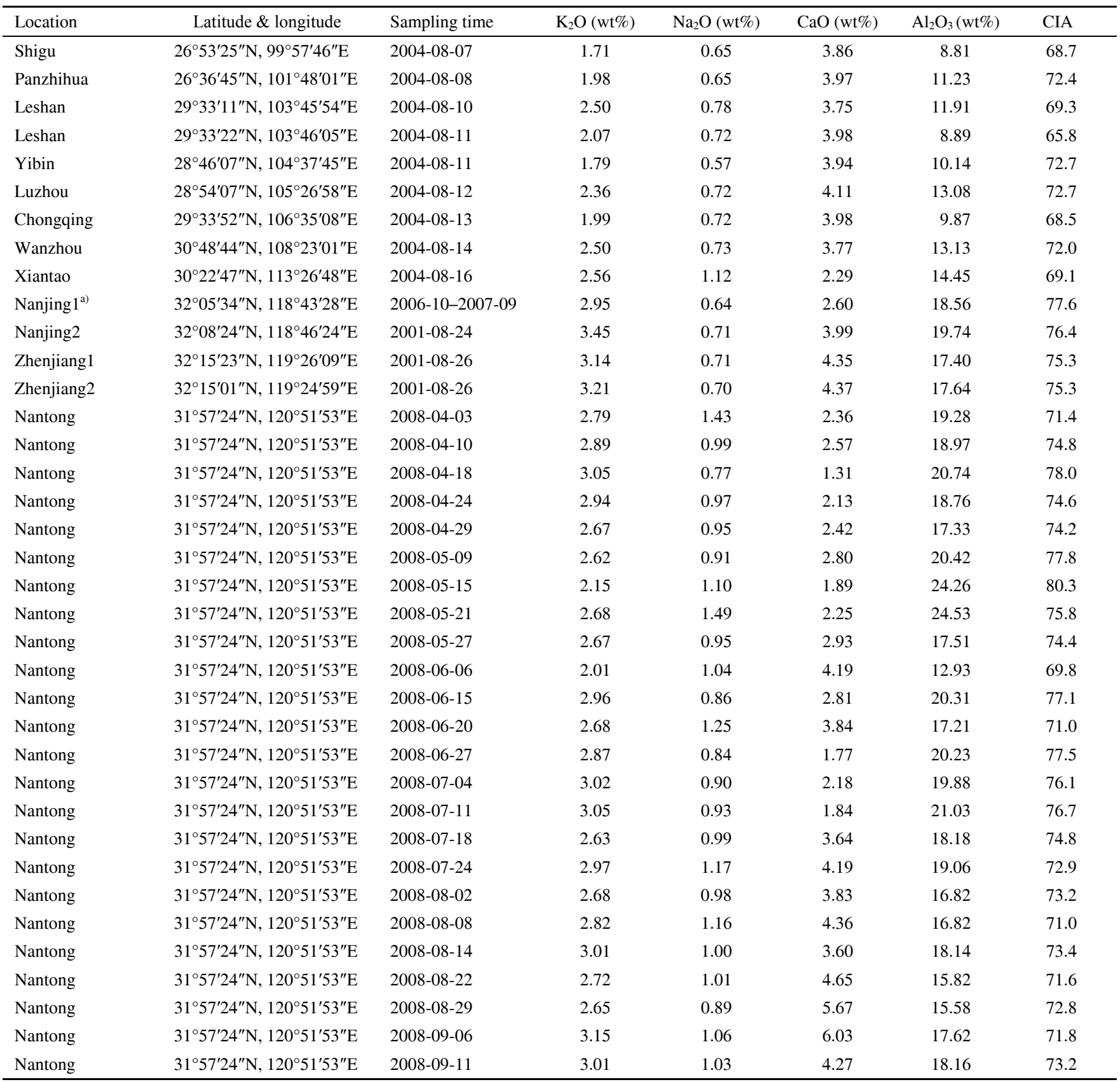




\begin{tabular}{|c|c|c|c|c|c|c|c|}
\hline & & & 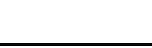 & \multicolumn{4}{|r|}{ (Continued) } \\
\hline Location & Latitude \& longitude & Sampling time & $\mathrm{K}_{2} \mathrm{O}(\mathrm{wt} \%)$ & $\mathrm{Na}_{2} \mathrm{O}(\mathrm{wt} \%)$ & $\mathrm{CaO}(\mathrm{wt} \%)$ & $\mathrm{Al}_{2} \mathrm{O}_{3}(\mathrm{wt} \%)$ & CIA \\
\hline Nantong & $31^{\circ} 57^{\prime} 24^{\prime \prime} \mathrm{N}, 120^{\circ} 51^{\prime} 53^{\prime \prime} \mathrm{E}$ & $2008-09-19$ & 2.60 & 1.18 & 5.79 & 14.99 & 69.1 \\
\hline Nantong & $31^{\circ} 57^{\prime} 24^{\prime \prime} \mathrm{N}, 120^{\circ} 51^{\prime} 53^{\prime \prime} \mathrm{E}$ & $2008-09-26$ & 2.81 & 1.10 & 5.71 & 16.41 & 71.1 \\
\hline Nantong & $31^{\circ} 57^{\prime} 24^{\prime \prime} \mathrm{N}, 120^{\circ} 51^{\prime} 53^{\prime \prime} \mathrm{E}$ & 2008-10-04 & 2.78 & 1.16 & 6.33 & 16.57 & 70.8 \\
\hline Nantong & $31^{\circ} 57^{\prime} 24^{\prime \prime} \mathrm{N}, 120^{\circ} 51^{\prime} 53^{\prime \prime} \mathrm{E}$ & 2008-10-11 & 3.03 & 0.90 & 4.74 & 17.97 & 74.2 \\
\hline Nantong & $31^{\circ} 57^{\prime} 24^{\prime \prime} \mathrm{N}, 120^{\circ} 51^{\prime} 53^{\prime \prime} \mathrm{E}$ & 2008-10-18 & 2.67 & 1.21 & 4.77 & 15.88 & 69.8 \\
\hline Nantong & $31^{\circ} 57^{\prime} 24^{\prime \prime} \mathrm{N}, 120^{\circ} 51^{\prime} 53^{\prime \prime} \mathrm{E}$ & $2008-10-25$ & 2.84 & 0.97 & 4.19 & 17.97 & 74.1 \\
\hline Nantong & $31^{\circ} 57^{\prime} 24^{\prime \prime} \mathrm{N}, 120^{\circ} 51^{\prime} 53^{\prime \prime} \mathrm{E}$ & 2008-11-01 & 2.92 & 1.01 & 4.48 & 17.75 & 73.2 \\
\hline Nantong & $31^{\circ} 57^{\prime} 24^{\prime \prime} \mathrm{N}, 120^{\circ} 51^{\prime} 53^{\prime \prime} \mathrm{E}$ & $2008-11-08$ & 3.06 & 0.84 & 2.29 & 21.50 & 77.9 \\
\hline Nantong & $31^{\circ} 57^{\prime} 24^{\prime \prime} \mathrm{N}, 120^{\circ} 51^{\prime} 53^{\prime \prime} \mathrm{E}$ & 2008-11-15 & 2.75 & 1.08 & 4.23 & 16.98 & 72.2 \\
\hline Nantong & $31^{\circ} 57^{\prime} 24^{\prime \prime} \mathrm{N}, 120^{\circ} 51^{\prime} 53^{\prime \prime} \mathrm{E}$ & $2008-11-22$ & 2.95 & 0.73 & 3.13 & 18.61 & 76.9 \\
\hline Nantong & $31^{\circ} 57^{\prime} 24^{\prime \prime} \mathrm{N}, 120^{\circ} 51^{\prime} 53^{\prime \prime} \mathrm{E}$ & 2008-11-29 & 2.84 & 0.93 & 4.64 & 17.89 & 74.4 \\
\hline Nantong & $31^{\circ} 57^{\prime} 24^{\prime \prime} \mathrm{N}, 120^{\circ} 51^{\prime} 53^{\prime \prime} \mathrm{E}$ & $2008-12-06$ & 2.82 & 0.85 & 3.16 & 19.40 & 76.8 \\
\hline Nantong & $31^{\circ} 57^{\prime} 24^{\prime \prime} \mathrm{N}, 120^{\circ} 51^{\prime} 53^{\prime \prime} \mathrm{E}$ & $2008-12-14$ & 2.67 & 1.01 & 3.74 & 17.16 & 73.3 \\
\hline Nantong & $31^{\circ} 57^{\prime} 24^{\prime \prime} \mathrm{N}, 120^{\circ} 51^{\prime} 53^{\prime \prime} \mathrm{E}$ & $2008-12-20$ & 2.95 & 0.96 & 3.01 & 20.12 & 76.0 \\
\hline Nantong & $31^{\circ} 57^{\prime} 24^{\prime \prime} \mathrm{N}, 120^{\circ} 51^{\prime} 53^{\prime \prime} \mathrm{E}$ & $2008-12-27$ & 2.88 & 0.91 & 3.80 & 18.91 & 75.5 \\
\hline Nantong & $31^{\circ} 57^{\prime} 24^{\prime \prime} \mathrm{N}, 120^{\circ} 51^{\prime} 53^{\prime \prime} \mathrm{E}$ & $2009-01-03$ & 2.98 & 0.98 & 3.40 & 19.44 & 75.0 \\
\hline Nantong & $31^{\circ} 57^{\prime} 24^{\prime \prime} \mathrm{N}, 120^{\circ} 51^{\prime} 53^{\prime \prime} \mathrm{E}$ & 2009-01-08 & 2.85 & 1.21 & 3.26 & 18.35 & 72.2 \\
\hline Nantong & $31^{\circ} 57^{\prime} 24^{\prime \prime} \mathrm{N}, 120^{\circ} 51^{\prime} 53^{\prime \prime} \mathrm{E}$ & 2009-01-15 & 2.71 & 1.01 & 4.00 & 16.80 & 72.9 \\
\hline Nantong & $31^{\circ} 57^{\prime} 24^{\prime \prime} \mathrm{N}, 120^{\circ} 51^{\prime} 53^{\prime \prime} \mathrm{E}$ & 2009-01-20 & 2.83 & 0.94 & 3.60 & 18.38 & 74.9 \\
\hline Nantong & $31^{\circ} 57^{\prime} 24^{\prime \prime} \mathrm{N}, 120^{\circ} 51^{\prime} 53^{\prime \prime} \mathrm{E}$ & 2009-02-04 & 2.83 & 1.11 & 3.38 & 17.99 & 72.8 \\
\hline Nantong & $31^{\circ} 57^{\prime} 24^{\prime \prime} \mathrm{N}, 120^{\circ} 51^{\prime} 53^{\prime \prime} \mathrm{E}$ & 2009-02-10 & 2.74 & 1.20 & 4.20 & 17.11 & 71.1 \\
\hline Nantong & $31^{\circ} 57^{\prime} 24^{\prime \prime} \mathrm{N}, 120^{\circ} 51^{\prime} 53^{\prime \prime} \mathrm{E}$ & 2009-02-18 & 2.87 & 1.28 & 2.41 & 19.32 & 72.5 \\
\hline Nantong & $31^{\circ} 57^{\prime} 24^{\prime \prime} \mathrm{N}, 120^{\circ} 51^{\prime} 53^{\prime \prime} \mathrm{E}$ & 2009-02-18 & 2.62 & 1.26 & 3.32 & 16.53 & 70.3 \\
\hline Nantong & $31^{\circ} 57^{\prime} 24^{\prime \prime} \mathrm{N}, 120^{\circ} 51^{\prime} 53^{\prime \prime} \mathrm{E}$ & 2009-03-08 & 2.61 & 0.97 & 2.53 & 18.42 & 75.4 \\
\hline Nantong & $31^{\circ} 57^{\prime} 24^{\prime \prime} \mathrm{N}, 120^{\circ} 51^{\prime} 53^{\prime \prime} \mathrm{E}$ & 2009-03-15 & 2.45 & 1.15 & 3.49 & 15.54 & 70.7 \\
\hline Nantong & $31^{\circ} 57^{\prime} 24^{\prime \prime} \mathrm{N}, 120^{\circ} 51^{\prime} 53^{\prime \prime} \mathrm{E}$ & 2009-03-22 & 2.70 & 0.87 & 1.88 & 18.51 & 76.1 \\
\hline Nantong & $31^{\circ} 57^{\prime} 24^{\prime \prime} \mathrm{N}, 120^{\circ} 51^{\prime} 53^{\prime \prime} \mathrm{E}$ & 2009-04-03 & 2.65 & 1.01 & 1.60 & 19.33 & 75.8 \\
\hline Changxing Island & $31^{\circ} 29^{\prime} 37^{\prime \prime} \mathrm{N}, 121^{\circ} 31^{\prime} 16^{\prime \prime} \mathrm{E}$ & $2001-08-28$ & 3.20 & 0.96 & 3.79 & 16.48 & 71.3 \\
\hline \multicolumn{2}{|c|}{ Mean of Nantong samples (51) } & & 2.79 & 1.03 & 3.50 & 18.30 & $73.9(75.8)$ \\
\hline \multicolumn{2}{|c|}{ Mean of all samples (65) } & & 2.73 & 0.97 & 3.56 & 17.32 & 72.1 \\
\hline \multicolumn{2}{|c|}{ Mean of World rivers $(16)^{\mathrm{b})}$} & & 2.60 & 1.33 & 3.84 & 17.98 & 71.6 \\
\hline \multicolumn{2}{|c|}{ Mean of World rivers $(60)^{\mathrm{c})}$} & & 2.04 & 0.96 & 3.63 & 16.47 & 75.5 \\
\hline \multicolumn{2}{|c|}{ Mean of World rivers $(44)^{\mathrm{d})}$} & & 2.55 & 1.21 & 3.57 & 16.4 & 72.1 \\
\hline
\end{tabular}

a) From [36]; b) from [29]; c) from [37]; d) from [20]. The number in parentheses refers to sample numbers studied, (75.8) refers to CIA values calculated by the acid leaching method and the other CIA values were calculated by McLennan's method.

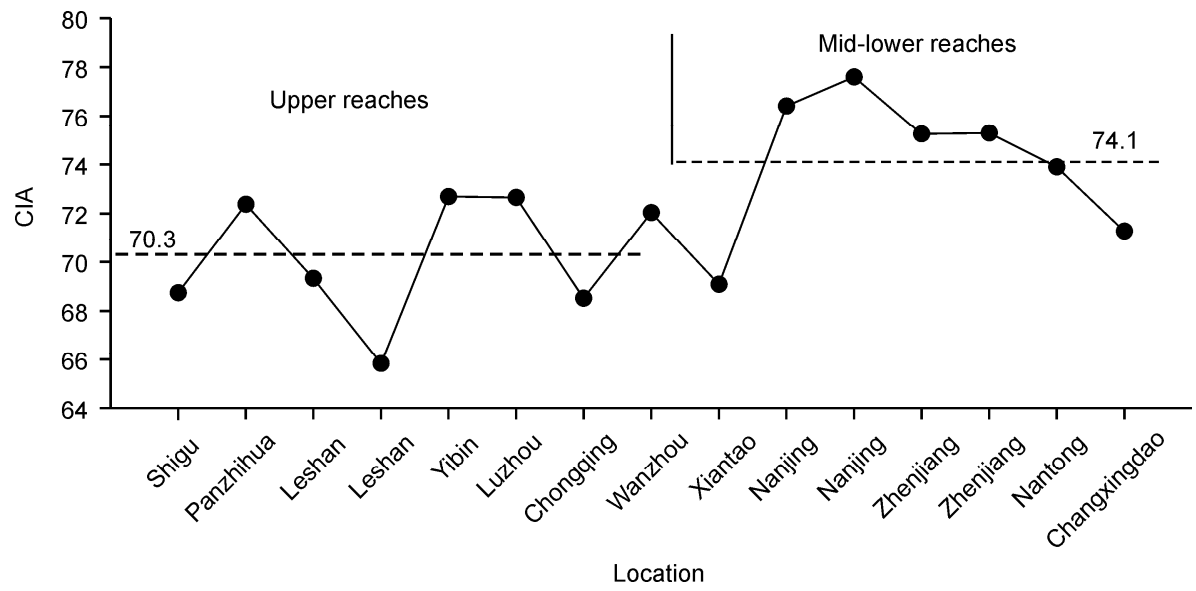

Figure 1 Spatial variation of the CIA values calculated from the Changjiang River SPM samples. 
lower than that by Viers et al. [37].

Climate has been suggested to predominantly control silicate weathering in the Changjiang River and Huanghe River basins while source rocks and other factors are subordinate [19]. Compared to the irregular variation of the CIA values in the world's major rivers, the CIA variation from China's major rivers implies that silicate weathering in latitudinal river basins is more sensitive to monsoon climate than to source rock, drainage area and physical denudation. Consequently, the CIA variation between the major rivers in China shows a good correlation with basinal average temperature, precipitation and runoff [20].

Long-term observation of suspended sediment load reveals that the SPM in the mid-lower mainstream is mainly derived from numerous tributaries in the upper valley $[38,39]$. The average CIA value in the mid-lower reaches is overall higher than those in the upper mainstream and major tributaries (Figure 1). As many studies have suggested, the CIA in sediments primarily reflects the integrated chemical weathering history from source areas $[20,40]$. Different CIA values between the upper and mid-lower reaches in this study suggests that the fine-grained SPM samples from the mid-lower reaches might have experienced stronger silicate weathering, and more silicate minerals altered to clays, relative to the upper reaches. The Changjiang River basin is strongly subject to Asian monsoon climate [41], and a majority of the catchment is located in the temperate to subtropical climate zone, but average temperature and precipitation is distinct between the upper and mid-lower reaches. Annual atmospheric precipitation ranges from 150 to 1000 $\mathrm{mm}$ in the upper reaches and average temperature varies at $\sim 5$ to $15^{\circ} \mathrm{C}$, while in the middle-lower reaches annual temperature is $\sim 16$ to $18^{\circ} \mathrm{C}$ with annual average precipitation reaching $1200 \mathrm{~mm} \mathrm{a}^{-1}[42,43]$. The Changjiang River basin is characterized by complex source rock compositions. In the upper reaches, the Emeishan basalt which is the largest basalt province in China, and the Cenozoic magmatic source rocks in the Tibetan Plateau are widespread. In comparison, the Indosinian and Yanshanian granites and ancient metamorphic rocks are widely distributed in the mid-lower reaches. Overall, the Changjiang River basin has complex source rock types from basic to acidic rocks, and there is no dominant source rock type from the upper to mid-lower reaches.

The tributary system of the Changjiang River is very complex, especially in the upper reaches where several large tributaries, such as the Jinsha River, Yalong River, Minjiang River, Dadu River, Jialing River, Wujiang River, and Tuojiang River are located. The SPM in these tributaries can reflect the average compositions of weathered materials from different source rocks, being representative of weathered upper continental crust [19]. Different monsoon climate regimes (e.g. temperature, rainfall, runoff and corresponding vegetation) in different regions of the Changjiang River catchment, are the predominant factor control- ling silicate weathering in the basins and account for stronger chemical weathering in the mid-lower reaches. Tectonically, the source regions of the Changjiang River, i.e. the Tibetan Plateau and surrounding upper reaches, are significantly affected by Cenozoic tectonic movement. Rapid uplift and physical denudation caused fresh rocks to be frequently exposed to chemical weathering. However, the soils are not well developed in the upper reaches mostly because of weak chemical weathering under adverse climate condition and rapid erosion.

In comparison, the mid-lower valley is primarily situated on the relatively stable Yangtze craton, and low relief and favorable monsoon climate are responsible for stronger chemical weathering. In addition, the broadening of the river and decreasing gradient of the river channel has led to a well developed floodplain in the mid-lower reaches. Chemical weathering of the floodplain sediments may significantly change the composition of river-borne particulate matter [44-46], causing enhanced CIA values in the midlower reaches. The contribution of floodplain weathering to the bulk composition of the Changjiang River sediments however requires more research.

The mineral composition of the Changjiang River SPM primarily consists of clay minerals $(\sim 30 \%-60 \%)$ and quartz $(\sim 20 \%)$, with minor amounts of feldspar and carbonate minerals. Overall, the clay mineral assemblages in different regions of the catchment are similar, but chlorite is relatively enriched in the upper reaches whereas kaolinite is concentrated in the mid-lower mainstream [47]. In addition, the chemical index and crystallinity index of illite gradually increases from the upper to mid-lower reaches, suggesting that more silicate minerals in the mid-lower reaches weathering to clays compared to the upper valley [36]. It is noteworthy that the upper terrain has higher relief and channel gradients, faster water flow and a stronger hydrodynamic force than the mid-lower reaches. This results in the coarser grain size of the SPM in the upper reaches [47]. Clay minerals are mostly enriched in fine particles, and therefore, to some extent, hydrodynamic sorting can affect the calculation of CIA. Some specific rivers such as the Minjiang have the lowest clay content [47], which may account for its extraordinarily low CIA value (Figure 1).

\subsection{Seasonal variation of CIA in the SPM samples}

The SPM samples taken from the lower Changjiang River mainstream near Nantong likely represents the bulk composition of the Changjiang River sediments into the sea, given that there is no significant contribution from other tributaries downstream Nantong to the estuary. The seasonal SPM samples collected near Nanjing and Nantong were measured to compare the seasonal variation of CIA. The Nanjing samples were collected monthly from October 2006 to September 2007 by Mao [47], while in this study we collected the Nantong samples weekly from April 2008 to April 2009 
(Table 1 and Figure 2).

Though the Nanjing and Nantong samples were collected from different locations and at different times, they share similar seasonal variations in CIA albeit with different absolute values (Figure 2). The SPM samples taken in the flood season (May to October) show an overall decreasing trend in CIA values. The lowest values were in August and September while the samples taken during the dry season (November to next April) had smaller CIA variability. During the flood season, the average CIA value is 73.6 for the Nantong samples and 76.1 for the Nanjing sample, while in the dry season, the average CIA values are 74.2 and 78.9 respectively. Therefore, the SPM samples taken in the flood season (mostly summer time) have lower CIA values than those taken in the dry season (mostly winter time), which is contrary to the notion that monsoon climate primarily drives chemical weathering and controls the CIA values in sediments.

The CIA values in the mid-lower Changjiang River SPM samples probably reflect the average composition of suspended sediments eroded from different sources from the upper river basin. The difference in CIA values in the seasonal samples is determined by changing sources of SPM into the lower mainstream. The Changjiang River catchment is significantly affected by Asian monsoon climate and the annual average precipitation shows a distinct distribution pattern in the basin [48]. Furthermore, the monsoonal rain front migrates considerably with time. For example, during the period from March to June, the rain (usually called Meiyu or plum rain) mainly distributes in the mid-lower reaches. In July, the rain front shifts westward to the Sichuan Basin in the upper reaches. In August and September, the rain front continues to move inland deep to the upper reaches. From October to next March however, this rain front, returns to the mid-lower reaches and the rain volume becomes smaller [48]. Intense rainfall and surface runoff directly control the physical erosion process of surface soil, transporting a large volume of weathered material and fresh debris into the river. Seasonal migration of the rain front in the Changjiang River basin causes significantly changing sources of the SPM into the lower reaches, i.e. altering the relative contribution of SPM from the upper and mid-lower valleys, which consequently, changes the CIA values of the SPM from the lower Changjiang River mainstream to the sea. During the flood or summer season from May to June, the monsoonal rain in the mid-lower reaches enhances physical weathering, which may erode and transport more surface soils with higher CIA values to the lower mainstream. However the monsoonal rain migrates to the upper reaches during July to September and intense physical erosion in the upper valley, may supply a large volume of detrital sediments with lower CIA values into the mainstream. From October to next March, the rain front moves back to the mid-lower valley, and moreover, the water
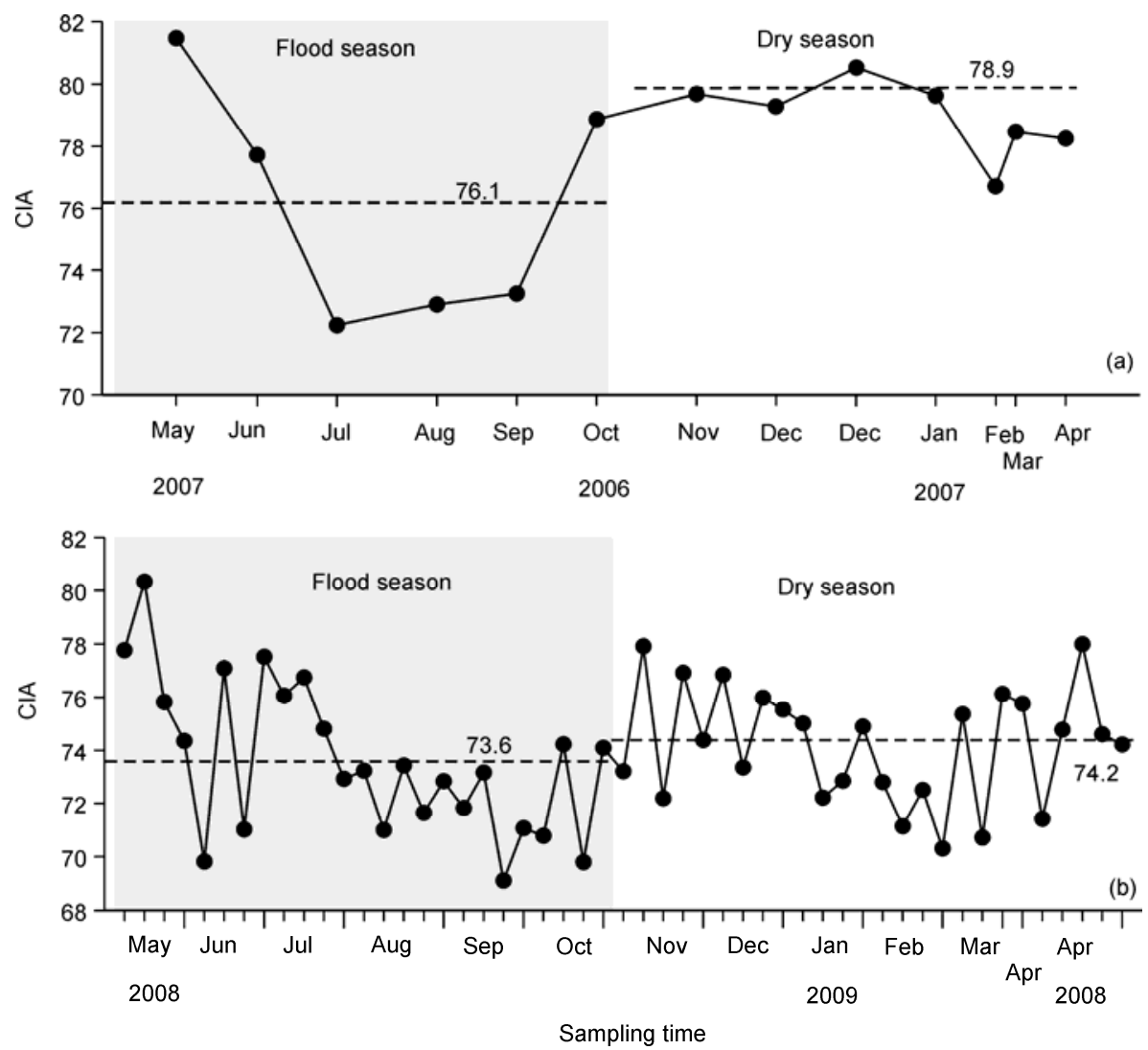

Figure 2 The seasonal variation of CIA values in the Changjiang River SPM samples. (a) Nanjing SPM samples [36]; (b) Nantong SPM samples (this study). 
impoundment of the Three Gorges Reservoir during the dry season can trap a large volume of suspended sediments eroded from the upper reaches [49-51]. These factors together will change the SPM source in the lower mainstream by receiving more sediments from the mid-lower valley, and consequently, cause the increasing trend of CIA value in the lower mainstream during the dry season (Figure 2).

The fluctuation of the CIA values in the dry or winter season (Figure 2) may also be related with the SPM contribution from those tributaries in the mid-lower valley. For example, in the Hanjiang River sediment the middle reaches are mainly from the loess area in its upper basin, such that the CIA value in the loess is low [19]. This causes the lower CIA value in the Hanjiang River SPM samples (Table1, Figure 1). Based upon the above discussion, this paper reconfirms that the proxy CIA primarily reflects the integrated chemical weathering history over longer time scales, but it cannot directly indicate instantaneous chemical weathering and seasonal climate change in continents because of sediment recycling. In summary, caution should be taken with time scales when using CIA as a proxy to indicate chemical weathering of silicate minerals and/or for reconstruction of paleoclimate evolution.

\section{Limitations of CIA calculation and applica- tion}

\subsection{Influence of different calculation methods on CIA values}

Since Nesbitt and Young [9] first proposed CIA as a proxy, it has been extensively applied to examine weathering. In the calculation formula of CIA, $\mathrm{CaO}^{*}$ denotes $\mathrm{CaO}$ content incorporated in silicate minerals, and thus, non- silicate $\mathrm{CaO}$ has to be removed from the samples before the calculation of CIA. In a simplified version, McLennan [29] proposed a correction method by comparing the relative contents of $\mathrm{Na}_{2} \mathrm{O}$ and $\mathrm{CaO}$ in sediments to estimate $\mathrm{CaO}^{*}$, which has been adopted by many researchers. However, the different influence of these two methods of estimating $\mathrm{CaO}^{*}$ on the CIA calculation has not been considered. In this paper, these two methods were adopted to calculate CIA values in the Nantong seasonal samples (Figure 3). The CIA values using McLennan's correction method are overall lower than those derived from the acid leaching method, with the difference ( $\triangle \mathrm{CIA}$ ) of $1-3$. The average CIA value obtained by the correction method is 73.9 , with standard deviation of $5.1(2 \sigma)$ and coefficient of variation of 3.5. In comparison, the average CIA value using the acid leaching method is 75.8 , with standard deviation of $4.8(2 \sigma)$ and coefficient of variation of 3.2. The coefficients of variation from two calculation methods (3.5 and 3.2) are higher than the analytic precision ( $1.5 \%$ for the elements $\mathrm{Al}, \mathrm{K}, \mathrm{Na}$, and $\mathrm{Ca}$ ), indicating that the difference of CIA values between two calculation methods is not caused by the analytic precision of the instrument, but related to the character of the sediment samples and the correction methods. The standard deviation of the calculated CIA by each method is higher than $\triangle$ CIA, implying that the different calculation methods cannot significantly alter the CIA values within the same sample (Figure 3). However, it is important that the calculation method is consistent in order to accurately compare the absolute CIA values from different areas.

\subsection{Constraints of sediment grain size on CIA}

Many geochemical proxies of sediments are controlled by particle size given that different elements are enriched in different size fractions. Mao [47] found that the CIA value in the

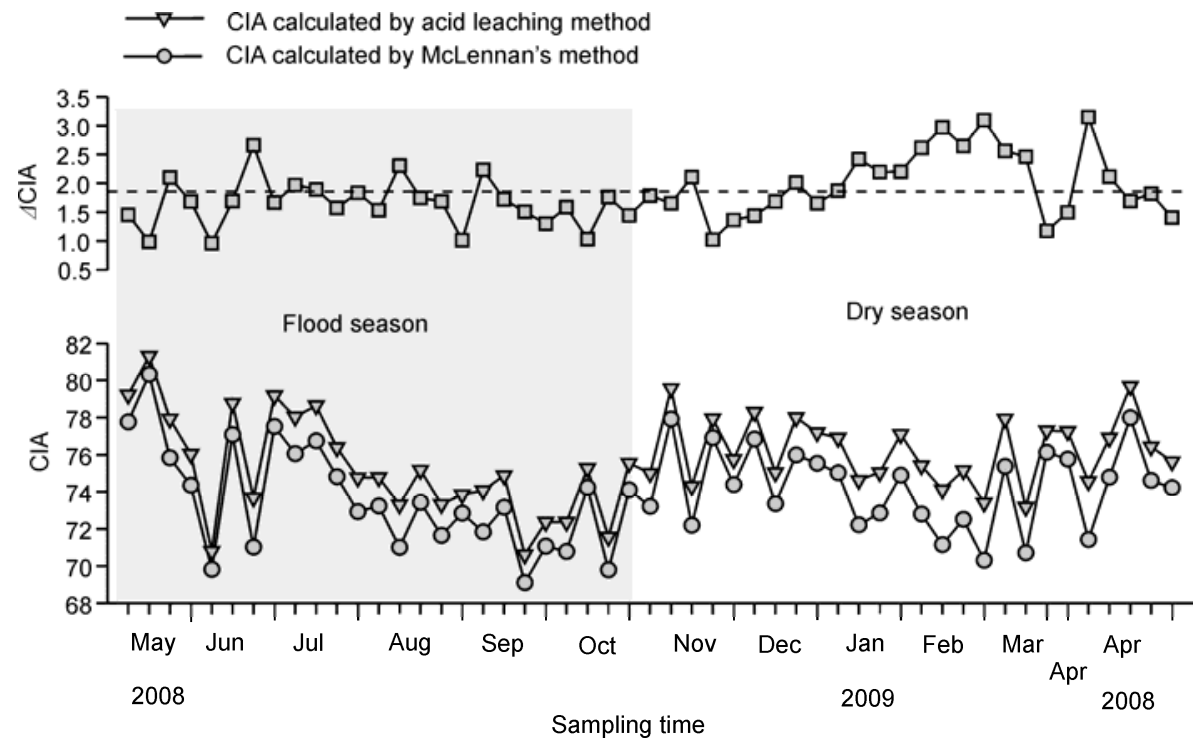

Figure 3 Comparison of the CIA values from the Nantong samples estimated by the two different methods. 
bank or bottom sediments is generally lower than in the suspended samples, and suggested that hydrodynamic sorting can result in high CIA values in clay-rich SPM samples.

This study reveals that the CIA values in both the floodplain sediments and SPM samples have a good correlation (Figure 4). Furthermore, the CIA values from different areas display different correlations with sediment grain size that were tested at the $P=0.01$ significance level. In the lower reaches of the Changjiang river, the CIA values in the floodplain sediments and SPM samples show a good correlation with the average grain size, $\left(R^{2}=0.79, P=0.01\right)$. Interestingly, average grain size has a higher correlation with CIA values in coarse-grained sediments $(\Phi<7.0)$ than in fine fraction $(\Phi>7.0)$ (Figure 4$)$. In the Changjiang River catchment, the SPM in the upper reaches is overall coarser and has lower CIA values, while the SPM in the mid-lower reaches is relatively finer with higher CIA value. It is noteworthy that the average grain size has a higher correlation with CIA value in the upper reaches $\left(R^{2}=0.49, P=0.01\right.$; Figure 4) than in the mid-lower reaches $\left(R^{2}=0.23, P=0.01\right.$; Figure 4). This clearly suggests that hydrodynamic sorting can affect the spatial variation of the CIA values of the Changjiang River SPM samples, with the finer samples containing more clay and yielding higher CIA values. However, if taking into account the average composition of the Nantong SPM samples, the grain size has a weaker influence on the CIA value as shown by their poor correlation (Figure 4). The SPM in the lower mainstream close to the estuary can be regarded as well-mixed weathered finegrained sediment from the whole Changjiang basin, and thus, the smaller size range of the SPM samples accounts for the poor correlation of the mean grain size and the CIA.

In summary, the use of CIA as a proxy to indicate weathering intensity requires consideration of the influence from the study area, sediment character and grain size. As a whole, the SPM in the lower mainstream of the large river in this study represents the average composition of the finegrained sediments weathered from the upper continental crust on the entire basin, and therefore, the CIA values pre- dominantly reflect the degree of integrated silicate weathering from the catchment.

\section{Conclusions}

(1) The CIA values from the Changjiang River SPM samples vary between 65.8 and 77.6 with an average of 72.1 , close to the average value of the world's major rivers. Generally, the CIA value in the upper reaches is lower than in the mid-lower reaches. The CIA as a proxy primarily reflects the integrated chemical weathering history, and the spatial variation of the CIA values in the Changjiang river system is mainly controlled by the monsoon climate.

(2) Clear seasonal variations in the CIA values were observed in the SPM samples taken from the lower Changjiang River mainstream. These values were higher in the dry season and lower in the flood season. This seasonal variation reflects the changing SPM sources in the mid- lower mainstream due to the migration of seasonal rainfall in the catchment, i.e. different and competing contributions from the upper and mid-lower reaches. This further suggests that the CIA cannot indicate instantaneous chemical weathering or seasonal climate change.

(3) Different calculation methods have a certain influence on the absolute CIA values, but for the large rivers such as the Changjiang River, it does not affect long-term time variability of the CIA values. In order to accurately compare the absolute CIA values from different study areas however, the consistency of CIA calculation is a prerequisite.

(4) The grain size of SPM exerts a relatively weak influence on the CIA value. The SPM in the lower mainstream close to the river mouth can represent the average composition of fine-grained sediments weathered from the upper continental crust on the whole basin, and its CIA value therefore, indicates the integrated chemical weathering in the basin. Thus, the representative suspended fine-grained sediment or the size-separated fraction is suggested for examination of continental weathering.
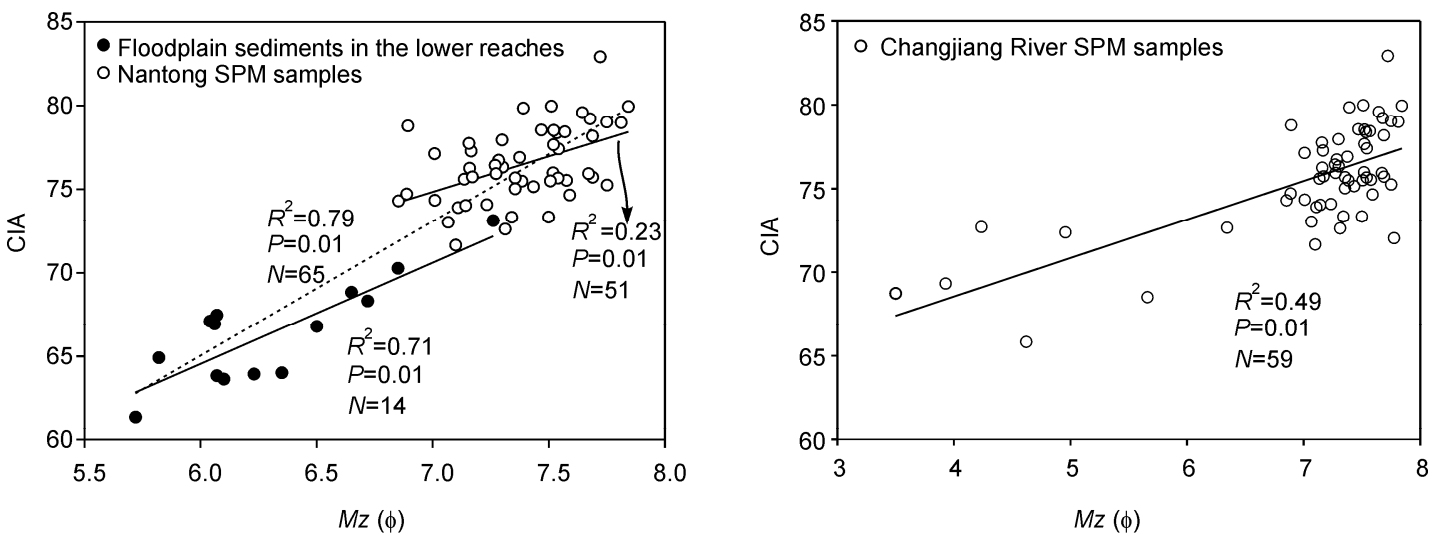

Figure 4 Correlations of the CIA values with mean grain size $(M z)$ from the Changjiang River sediments. 
This work was supported by the National Natural Science Foundation of China (41076018 and 40830107), and the Foundation of Key Laboratory of Yangtze River Water Environment, Ministry of Education (Tongji University, YRWEY 1009). We thank the reviewers and invited editor for their constructive comments.

1 Raymo M E, Ruddiman W, Froelich P N. Influence of late Cenozoic mountain building on ocean geochemical cycles. Geology, 1988, 16: 649-653

2 Berner R A, Lasaga A C, Garrels R M. The carbonate-silicate geochemical cycle and its effect on atmospheric carbon dioxide over the past 100 million years. Am J Sci, 1983, 283: 641-683

3 Raymo M E, Ruddiman W F. Tectonic forcing of late Cenozoic climate. Nature, 1992, 359: 117-122

4 Krishnaswami S, Trivedi J R, Sarin M M, et al. Strontium isotopes and rubidium in the Ganges Brahmaputra river system weathering in the Himalaya, fluxes to the Bay of Bengal and contribution to the evolution of oceanic $\mathrm{Sr}^{87} / \mathrm{Sr}^{86}$. Earth Planet Sci Lett, 1992, 109: 243-253

5 Suchet P A, Probst J L. Modeling of atmospheric $\mathrm{CO}_{2}$ consumption by chemical weathering of rocks: Application to the Garonne, Congo and Amazon basins. Chem Geol, 1993, 107: 205-210

6 Kump L R, Brantley S L, Arthur M A. Chemical weathering, atmospheric $\mathrm{CO}_{2}$, and climate. Annu Rev Earth Planet Sci, 2000, 28: 611667

7 Pierson-Wickmann A C, Reisberg L, France-Lanord C, et al. Os-Sr$\mathrm{Nd}$ results from sediments in the Bay of Bengal: Implication for sediment transport and the marine Os record. Paleoceanography, 2001, 16: 435-444

8 Short N M. Geochemical variation in four residual soils. J Geol, 1961, 69: 534-571

9 Nesbitt H W, Young G M. Early Proterozoic climate and plate motion inferred from major element chemistry of lutites. Nature, 1982, 299: 715-717

10 Harnois L. The CIW index: A new chemical index of weathering. Sediment Geol, 1988, 55: 319-322

11 Sueoka T. Identification and classification of granitic residual soils using chemical weathering index. In: Proceedings of the Second International Conference on Geomechanics in Tropical Soils, Singapore. 1988, 1: 55-61

12 Fedo C M, Nesbitt H W, Young G M. Unraveling the effects of potassium metasomatism in sedimentary rocks and paleosols, with implications for paleo-weathering conditions and provenance. Geology, 1995, 23: 921-924

13 Gaillardet J, Dupre B, Allegre C J. Geochemistry of large river suspended sediments: Silicate weathering or recycling tracer. Geochim Cosmochim Acta, 1999, 63: 4037-4051

14 Duzgoren-Aydin N S, Aydin A. Indices for scaling and predicting weathering-induced changes in rock properties. Environ Eng Geosci, 2002, 2: 121-135

15 Price J R, Velbel M A. Chemical weathering indices applied to weathering profiles developed on heterogeneous felsic metamorphic parent rocks. Chem Geol, 2003, 202: 397-416

16 Ohta T, Arai H. Statistical empirical index of chemical weathering in igneous rocks: A new tool for evaluating the degree of weathering. Chem Geol, 2007, 240: 280-297

17 Roddaz M, Viers J, Brusset S, et al. Controls on weathering and provenance in the Amazonian foreland basin: Insights from major and trace element geochemistry of Neogene Amazonian sediments. Chem Geol, 2006, 226: 31-65

18 Vital H, Stattegger K. Major and trace elements of stream sediments from the lowermost Amazon River. Chem Geol, 2000, 168: 151-168

19 Yang S Y, Jung H S, Li C X. Two unique weathering regimes in the Changjiang and Huanghe drainage basins: Geochemical evidence from river sediments. Sediment Geol, 2004, 164: 19-34

20 Li C, Yang S Y. Is chemical index of alteration a reliable proxy for chemical weathering in global drainage basins? Am J Sci, 2010, 310: 111-127

21 Ahmad T, Khanna P P, Chakrapani G J, et al. Geochemical charac- teristics of water and sediment of the Indus River, Trans-Himalaya, India: Constraints on weathering and erosion. J Asian Earth Sci, 1998, 16: 333-346

22 Singh M, Sharma M, Tobschall H J. Weathering of the Ganga alluvial plain, northern India: Implications from fluvial geochemistry of the Gomati River. Appl Geochem, 2005, 20: 1-21

23 Tripathi J K, Ghazanfari P, Rajamani V, et al. Geochemistry of sediments of the Ganges alluvial plains: Evidence of large-scale sediment recycling. Quatern Int, 2007, 159: 119-130

24 Borges J, Huh Y, Moon S, et al. Provenance and weathering control on river bed sediments of the eastern Tibetan Plateau and the Russian Far East. Chem Geol, 2008, 254: 52-72

25 Liu Z, Zhao Y L, Colin C, et al. Chemical weathering in Luzon, Philippines from clay mineralogy and major-element geochemistry of river sediments. Geochemical, 2009, 24: 2195-2205

26 Selvaraj K, Chen T A. Moderate Chemical Weathering of Subtropical Taiwan: Constraints from Solid-Phase Geochemistry of Sediments and Sedimentary Rocks. J Geol, 2006, 114: 101-116

27 Qiao Y S, Zhao Z Z, Wang Y, et al. Variations of geochemical compositions and the paleoclimatic significance of a loess-soil sequence from Garzê County of western Sichuan Province, China. Chin Sci Bull, 2010, 55: 255-260

28 Yao Z Q, Xiao G Q, Liang M Y. BZ_2 drilling sediment's geochemical composition of major element and chemical weathering in China North Plain. Chin Sci Bull, 2009, 54: 3400-3403

29 McLennan S M. Weathering and global denudation. J Geol, 1993, 101: 295-303

30 Yang S Y, Li C X. Elemental composition in the sediments of the Yangtze and the Yellow Rivers and their tracing implication. Prog Nat Sci, 2000, 10: 612-618

31 Kautz C Q, Martin C E. Chemical and physical weathering in New Zealand's Southern Alps monitored by bedload sediment major element composition. Appl Geochem, 2007, 22: 1715-1735

32 Nesbitt H W, Young G M. Prediction of some weathering trends of plutonic and volcanic rocks based on thermodynamic and kinetic considerations. Geochim Cosmochim Acta, 1984, 48: 1523-1534

33 Nesbitt H W, Young G M. Formation and diagenesis of weathering profiles. J Geol, 1989, 97: 129-147

34 Chen J, Wang H T, Lu H Y. Behaviors of REE and other trace elements during pedological weathering-Evidence from chemical leaching of loess and paleosol from the Luochuan section in central China (in Chinese). Acta Geol Sin, 1996, 70: 61-72

35 Song Y H, Choi M S. REE geochemistry of fine-grained sediments from major rivers around the Yellow Sea. Chem Geol, 2009, 266: 328-342

36 Mao C P, Chen J, Yuan X, et al. Seasonal variation the mineralogy of the suspended particulate matter of the lower Changjiang River at Nanjing, China. Clays Clay Miner, 2010, 58: 691-706

37 Viers J, Dupre B, Gaillardet J. Chemical composition of suspended sediments in World River: New insights from a new database. Sci Total Environ, 2008, 407: 853-868

38 Yang S L, Zhao Q Y, Belkin I M. Temporal variation in the sediment load of the Yangtze River and the influences of human activities. J Hydrol, 2002, 263: 56-71

39 Wang Z Y, Huang W D, Li Y T. Sediment budget of the Yangtze River (in Chinese). J Sed Res, 2007, 2: 1-10

40 Potter P E, Maynard J B, Depetris P J. Mud and Mudstones. Berlin: Springer, 2005. 157-174

41 Chen Z, Gupta A, Yin H F. Monsoon rivers of Asia. Geomorphology, 2007, 85: 129-130

42 Chen J S. Principle of River Water Quality in China (in Chinese). Beijing: Science Press, 2006. 103-126

43 Chen Z Y, Wang Z H, Finlayson B, et al. Implication of flow control by the Three Gorges Dam on sediment and channel dynamics of the middle Yangtze (Changjiang) River, China. Geol Soci Am, 2010, 38: 1043-1046

44 Johnsson M J, Meade R H. Chemical weathering of fluvial sediments during alluvial storage: The Macupanim Island point bar, Solimoes River, Brazil. J Sediment Petrol, 1990, 60: 827-842 
45 Derry L A, France-Lanord C. Neogene Himalayan weathering history and river ${ }^{87} \mathrm{Sr} /{ }^{86} \mathrm{Sr}$ : Impact on the marine Sr record. Earth Planet Sci Lett, 1996, 142: 59-76

46 Heller P L, Peter E B, Humphrey N F, et al. Paradox of downstream fining and weathering-rind formation in the lower Hoh River, Olympic Peninsula, Washington. Geology, 29: 971-974

47 Mao C P. Geochemical and mineralogical studies of the sediment (suspended sediment) in Changjiang River Drainage Basin (in Chinese). Dissertation for the Doctoral Degree. Nanjing: Nanjing University, 2009

48 Tang J J. The temporal and spatial distribution of precipitation over
Yangtze River Catchment from 1952 to 2007-Case study of precipitation redistribution under global warming (in Chinese). Dissertation for the Master's Degree. Shanghai: East China Normal University, 2010

49 Dai S B, Yang S L, Zhao H Y, et al. Response of middle and lower reaches of Yangtze River to the initial operation stage of the Three Gorges Project (in Chinese). J Sediment Res, 2005, 5: 35-39

50 Xu B K, Milliman J D, Yang Z, et al. Yangtze sediment decline partly from Three Gorges Dam. EOS, 2006, 87: 185-196

51 Yang Z, Wang H, Saito Y, et al. Dam impacts on the Changjiang (Yangtze) River sediment discharge to the sea: The past 55 years and after the Three Gorges Dam. Water Resour Res, 2006, 42: 1-10

Open Access This article is distributed under the terms of the Creative Commons Attribution License which permits any use, distribution, and reproduction in any medium, provided the original author(s) and source are credited. 